\title{
Predictors of reading literacy for first and second language learners
}

\author{
Andrea Netten $\cdot$ Mienke Droop $\cdot$ Ludo Verhoeven
}

Published online: 13 May 2010

(C) The Author(s) 2010. This article is published with open access at Springerlink.com

\begin{abstract}
In this study an attempt was made to construct a multi-factor model predicting the development of reading literacy in the upper grades of primary school in the Netherlands for subgroups of 729 first language (L1) learners and 93 second language (L2) learners. Following a longitudinal design, it was explored to what extent the variation in reading literacy development in L1 and L2 from grade 4 to grade 6 can be explained from children's word decoding, language, mathematics and nonverbal reasoning skills, reading motivation and self confidence as well as their home reading resources. The results showed that L1 and L2 learners differed in reading literacy skills, language, mathematics, and reasoning skills. Structural equation modelling showed that the reading literacy development in both L1 and L2 learners could be explained from decoding, language, mathematics and reasoning skills, as well as their motivation and self-confidence. A striking difference was the fact that home reading resources had an impact on reading literacy in L1 learners but not in L2 learners.
\end{abstract}

Keywords Second language reading · Reading literacy · Word decoding · Motivation $\cdot$ Home reading resources

\footnotetext{
A. Netten $(\bowtie) \cdot$ M. Droop

National Center for Language Education, Radboud University Nijmegen, P.O. Box 6610, 6503 GC Nijmegen, The Netherlands

e-mail: A.Netten@taalonderwijs.nl

L. Verhoeven

Behavioural Science Institute, Radboud University Nijmegen, P.O. Box 9104,

6500 HE Nijmegen, The Netherlands
} 


\section{Introduction}

For a student to become a successful and productive adult in society, good reading skills are essential. To refer to the demands for literacy in today's society the term reading literacy was introduced as "the ability to understand and use those written language forms required by society and/or valued by the individual" (Mullis, Kennedy, Martin, \& Sainsbury, 2006, p. 3). Reading literacy and the factors that are associated with that ability have been a topic for study for many researchers. The Simple View of Reading states that reading comprehension is a product of two components; decoding and linguistic comprehension (Gough \& Tunmer, 1986; Hoover \& Gough, 1990). Decoding is the ability to transform printed letter strings into a phonetic code (Perfetti, 1985). Linguistic comprehension is, according to Gough and Tunmer (1986) "the process by which given lexical information, sentences and discourses are interpreted" (p. 7). Although many researchers have tried to modify, complicate and refute this theory (Joshi \& Aaron, 2000; Adlof, Catts, \& Little, 2006), there seems to be a consensus that these components form the basis of reading comprehension abilities (Perfetti, Landi, \& Oakhill, 2005). However, Joshi, Williams, and Wood (1998) found that although the components of the simple view of reading, decoding and language comprehension accounted for most of the variance in reading comprehension, IQ was also a significant predictor. Another related factor is mathematics. Reading literacy and mathematics involve similar cognitive demands which could explain the relationship that is observed between reading and mathematics in several studies (Lerkkanen, Rasku-Puttonen, Aunola, \& Nurmi, 2005). Lundberg and Sterner (2005) found close to forty percent of shared variance between reading literacy achievement and mathematics.

Background characteristics may also contribute to the variance in reading literacy. It has indeed been found that parents contribute to the reading abilities of their children through various environmental factors, such as motivational factors, reading literacy activities, and reading attitudes (Tabors \& Snow, 2001). Snow and Beals (2006) demonstrated that besides literacy activities, such as reading a book together with a child, even those natural interactions between parent and child that occur during day to day activities can contribute to children's literacy abilities. In a similar vein, de Jong and Leseman (2001) examined the impact of preschool home environment for later literacy development in primary school. They found that even after first grade word-decoding ability and reading comprehension were controlled for, home measures remained to have an impact on third grade reading comprehension. Reading can thus be seen as an activity which benefits from practice, and it can be assumed that for many children a great deal of that practice takes place at home. A positive and reciprocal relationship between children's reading ability, the time they spent reading, and their reading motivation has indeed been found (Guthrie \& Wigfield, 2000). Cox and Guthrie (2001) also made clear that, when other factors such as ability were controlled for, the amount of reading for enjoyment was predicted most highly by reading motivation. Another factor by which parents influence their children's reading achievement is academic selfconfidence. Parents' positive beliefs and expectations about their children's abilities have a strong influence on their children's own beliefs about their academic abilities 
(Meece, Bower-Glienke, \& Burg, 2006). Students who have positive experiences and believe that they will do well in school turn out to obtain better school results (Aunola, Nurmi, Niemi, Lerkkanen, \& Rasku-Puttonen, 2002).

An important factor in children's background is the language spoken at home. Several studies have shown that second language learners lag behind their first language peers in reading literacy skills (Droop \& Verhoeven, 2003; Organisation for Economic Co-operation and Development [OECD], 2007; Mullis, Martin, Gonzales, \& Kennedy, 2003; Mullis, Martin, Kennedy, \& Foy, 2007; van der Veen, van der Meijden, \& Ledoux, 2004). Second language students are often faced with the complex task of learning to read in a language they are not accustomed to speak before they enter primary education. Given that learning to read comes down to learning to connect the spoken form of a language with the printed form (Wang, Perfetti, \& Liu, 2005), a problem for second language learners can be expected. Indeed, research has shown that problems with the spoken second language may have an impact on reading processes, especially in the domain of reading comprehension skills (Geva \& Verhoeven, 2000; Verhoeven, 2000). Several studies have also shown that in case of a mismatch between children's language abilities and the language being used in the school curriculum the reading motivation and self-confidence of L2 learners may be threatened (Aarnoutse, van Leeuwe, Voeten, \& Oud, 2001; Guthrie, Coddington, \& Wigfield, 2010). Besides linguistic factors, cognitive factors, such as mathematics and reasoning skills may also play a substantial role in the acculturation and reading acquisition of the L2 learner (Marks, 2005; van Diepen, 2007).

To conclude, previous research has shown that differences in reading literacy among both L1 and L2 learners can be accounted for by factors on the part of the child, such as word decoding, language, mathematics, general (nonverbal) cognitive skills, reading motivation, and self-confidence, as well as home factors, related to the quantity and quality of parental input. However, in most of the studies conducted so far a comparative explanatory model of differences in reading literacy for L1 vs. L2 learners was generally lacking. Therefore, the present study followed a multifactor approach to arrive at a general explaining model of the differences in reading literacy development among first and second language learners in the upper grades of primary education in the Netherlands. Following a longitudinal design, it was explored to what extent the variation in reading literacy development in L1 and L2 from grade 4 to grade 6 can be explained from children's word decoding, language, mathematics, and nonverbal reasoning skills, reading motivation, and self confidence as well as their home reading resources. An attempt was made to find an answer to the following questions:

1. What are the differences between L1 and L2 learners in reading literacy, decoding, language, mathematics, and nonverbal reasoning skills, reading motivation and self-confidence, and home reading resources?

2. Can the reading literacy development of L1 and L2 learners to the same extent be explained from their decoding, language, mathematics, and nonverbal reasoning skills, reading motivation and self-confidence, and home reading resources? 


\section{Method}

\section{Participants}

A representative sample of 822 children from 48 schools participated in the present study. These children form part of the so-called PRIMA study, a longitudinal cohort study on the learning of language, mathematics and reading abilities among students in elementary education in the Netherlands (Driessen, van Lange, \& Vierke, 2002). Seven hundred twenty-nine of the participants (340 boys, 389 girls) were first language learners with both parents born in the Netherlands, the remaining 93 students (54 boys, 39 girls) had parents originating from other countries (66\% from Mediterranean countries, $20 \%$ from ex-colonies, $14 \%$ other countries) and were considered second language learners.

\section{Materials}

\section{Reading literacy}

The level of reading literacy ability was assessed with the grade 4 and grade 6 versions of the standardized CITO Reading Comprehension Test (Staphorsius \& Krom, 1998). This test consists of texts with multiple-choice questions which comprise a scale for reading literacy throughout the elementary grades. The tests for both the fourth and the sixth grade consist of three parts with 25 multiple choice questions each. The first module of the test was equal for all students, after which the score on the test determined whether the students took a difficult or an easier module in part two of the testing. The total number of correct answers was then transformed into a scaled achievement score, which ranges between 0 and 100 .

\section{Language test}

The test was designed to give an indication of the general proficiency level in Dutch. The test tested three types of linguistic skills: Morphological, Syntactical, and Semantic (Instituut voor Toegepaste Sociologie [ITS], 1994a). The students had to evaluate whether each of the 59 sentences in the test were correct or incorrect. The internal consistency of this task was good with a Cronbach's alpha of .77.

\section{Decoding test}

Decoding skill was assessed using a standardized Dutch word-reading test, the Three Minutes Test (Verhoeven, 1995). Only Card 3 of the test was administered, which has less frequent polysyllabic words of increasing difficulty. The students were required to read as many words as possible out loud in $1 \mathrm{~min}$. The score was the total number of words read correctly. The internal consistency of this task was high with a Cronbach's alpha of .90 . 


\section{Nonverbal Reasoning test}

Nonverbal Reasoning was measured using two subtests of a nonverbal intelligence test (ITS, 1994b): Composing Figures and Exclusion. Composing Figures involved 19 items requiring the child to identify the missing part of a figure out of four alternatives. Exclusion involved 15 items requiring the child to identify the deviant figure out of four alternatives. The internal consistency of this task was good with a Cronbach's alpha of .77.

\section{Mathematics Test}

The CITO Calculation and Mathematics Test contain 83 items concerned with numbers, measurement and time (Janssen, Kraemer, \& Noteboom, 1995). The internal consistency of the task was high with a Cronbach's alpha of .89.

\section{Reading Motivation}

The scale consisted of eight items from the IEA Student Questionnaire (International Association for the Evaluation of Educational Achievement [IEA], 2001). The scale concerned the frequency of reading for fun outside school, reading stories, novels outside school, borrowing books from the library to read outside school, reading silently in school and the responses to the following four statements: 'I only read if I have to' (reverse coded), 'I would be happy if someone gave me a book as a present'; 'I think reading is boring' (reverse coded), 'I enjoy reading'. The internal consistency of this task was good with a Cronbach's alpha of .77.

\section{Academic Self-confidence}

The scale consisted of five items taken from the PRIMA Questionnaire (Driessen et al., 2002): 'I perform generally well'; 'I am one of the best students in the class'; 'most of the children in my class perform better than I do' (reverse coded); 'my teacher thinks I perform well'; 'I don't need a lot of help at school'. The internal consistency of this task was good with a Cronbach's alpha of .75.

\section{Home Reading Resources}

The scale consisted of three items related to the number of books in the home, the presence of a computer and a newspaper in the home. The internal consistency of this task was high with a Cronbach's alpha of .91 .

\section{Procedure}

All variables were collected in grade 4. Reading Literacy was again measured in grade 6 . Trained master students administered the data. The test for word decoding was administered individually, all other tests were administered group-wise. 
In order to address the first question, t-tests were conducted to test differences between predictor measures, and analysis of variance with repeated measures was undertaken to examine the development of reading literacy across grades.

To find an answer to the second question, a series of LISREL analyses (Version VIII, Jöreskog \& Sörbom, 1993) was conducted to explore the relations between the children's reading literacy and its predictors. An attempt was made to design a structural model with Nonverbal Reasoning and Home Reading Resources as background variables, Decoding, Language, Mathematics, Reading Motivation, and Academic Self-confidence as intermediate variables, and Reading Literacy in grade 4 and 6 as criterion variable. To determine whether the model predicts reading literacy results in grade 6 for both first and second language learners, and whether the strengths of the relationships between the entered variables are similar for the two subgroups, the model was tested using data for L1 and L2 learners, separately. The parameters of the model were estimated using a Maximum Likelihood procedure. The Goodness-of-fit of the proposed model was evaluated with five indicators, according to Hu and Bentler's (1999) criteria: the ratio of the chi-square value to the degrees of freedom (less than 3), the Goodness of Fit Index $(\mathrm{GFI}>.85)$, the Adjusted Goodness of Fit (AGFI $>.90)$; Normed Fit Index $(\mathrm{NFI}>.90)$; Root Mean Square Error of Approximation (RMSEA < .08).

\section{Results}

Differences between L1 and L2 learners

Table 1 presents the means and standard deviations of all measured variables for L1 and L2 learners. From t-test analyses, it was evidenced that the differences in mean scores on Nonverbal Reasoning $(t(820)=-2.53, p<.01)$, Home Reading Resources $(t(820)=-8.23, p<.001)$, Language $(t(820)=8.24, p<.001)$, and Mathematics $(t(820)=-4.71, p<.001)$ were significant. In addition, analysis of variance on the Reading Literacy results with Grade (4 vs 6) and Group (L1 vs. L2) as factors showed a significant effect for Group $(F(1,820)=46.06, p<.001)$ and Grade $(F(1,820)=1074.40, p<.001)$ with no significant interaction $(F(1$, $820)=.94, p>.05)$.

\section{Structural relations for L1 and L2 learners}

The preliminary analysis was to examine the correlations between the predictor and criterion variables for L1 and L2 learners, as shown in Table 2. The overall pattern looks quite similar for L1 and L2 learners. For both groups, a strong autocorrelation between Reading Literacy as measured in grades 4 and 6. A significant correlation was also found between Reading Literacy, on the one hand, and predictor measures, on the other hand, with the exception of Home Reading Resources which showed only a significant correlation in the group of L1 learners.

To begin with, a structural model was constructed for L1 students entering all background and intermediate variables in the model (see Fig. 1). The standardized 
Table 1 Means and standard deviations on predictor and criterion variables for L1 and L2 learners

\begin{tabular}{|c|c|c|c|c|}
\hline & \multicolumn{2}{|c|}{ L1 learners } & \multicolumn{2}{|c|}{ L2 learners } \\
\hline & $M$ & SD & $M$ & $\mathrm{SD}$ \\
\hline Nonverbal Reasoning (max 34) & 26.36 & 4.23 & 25.17 & 4.65 \\
\hline Home Reading Resources $(\max 2)$ & 1.71 & .23 & 1.50 & .26 \\
\hline Decoding (max 116) & 72.50 & 16.37 & 70.63 & 17.44 \\
\hline Language $(\max 1197,40)$ & 1085.95 & 32.81 & 1062.49 & 28.28 \\
\hline Mathematics $(\max 131)$ & 96.80 & 9.08 & 91.88 & 10.41 \\
\hline Reading Motivation $(\max 4)$ & 1.96 & .68 & 1.97 & .67 \\
\hline Academic Self-confidence ( $\max 5)$ & 3.28 & .71 & 3.29 & .67 \\
\hline Reading Literacy grade 4 (max 100) & 38.20 & 14.98 & 27.24 & 12.59 \\
\hline Reading Literacy grade $6(\max 100)$ & 58.46 & 16.06 & 48.17 & 15.16 \\
\hline
\end{tabular}

Table 2 Correlations between variables for L1 learners (upper row) and L2 learners (lower row)

\begin{tabular}{|c|c|c|c|c|c|c|c|c|}
\hline & $\begin{array}{l}\text { Nonverbal } \\
\text { Reasoning }\end{array}$ & $\begin{array}{l}\text { Home } \\
\text { read }\end{array}$ & Decoding & Language & Math & $\begin{array}{l}\text { Reading } \\
\text { Motivation }\end{array}$ & $\begin{array}{l}\text { Academic } \\
\text { Self- } \\
\text { confidence }\end{array}$ & $\begin{array}{l}\text { Reading } \\
\text { Literacy } \\
\text { grade } 4\end{array}$ \\
\hline $\begin{array}{l}\text { Home Reading } \\
\text { Resources }\end{array}$ & $\begin{array}{l}.20^{* *} \\
-.01\end{array}$ & & & & & & & \\
\hline Decoding & $\begin{array}{l}.05 \\
.16\end{array}$ & $\begin{array}{l}.18 * * \\
-.15\end{array}$ & & & & & & \\
\hline Language & $\begin{array}{l}.30^{* *} \\
.32^{* *}\end{array}$ & $\begin{array}{l}.21^{* *} \\
.00\end{array}$ & $\begin{array}{l}.45^{* *} \\
.29 * *\end{array}$ & & & & & \\
\hline Math. & $\begin{array}{l}.44^{* *} \\
.43^{* *}\end{array}$ & $\begin{array}{l}.19^{* *} \\
-.09\end{array}$ & $\begin{array}{l}.29 * * \\
.33 * *\end{array}$ & $\begin{array}{l}.46^{* *} \\
.49 * *\end{array}$ & & & & \\
\hline $\begin{array}{l}\text { Reading } \\
\text { Motivation }\end{array}$ & $\begin{array}{l}.09 \\
-.03\end{array}$ & $\begin{array}{l}.15^{* *} \\
.11\end{array}$ & $\begin{array}{l}.26^{* *} \\
.21^{*}\end{array}$ & $\begin{array}{l}.30^{* *} \\
.28^{* *}\end{array}$ & $\begin{array}{l}.12^{* *} \\
-.10\end{array}$ & & & \\
\hline $\begin{array}{l}\text { Academic Self- } \\
\text { confidence }\end{array}$ & $\begin{array}{l}.19^{* *} \\
.23^{*}\end{array}$ & $\begin{array}{r}.12 * \\
-.16\end{array}$ & $\begin{array}{l}.17 * * \\
.08\end{array}$ & $\begin{array}{l}.22 * * \\
.13\end{array}$ & $\begin{array}{l}.45^{* *} \\
.42^{* *}\end{array}$ & $\begin{array}{l}.08 * \\
.08\end{array}$ & & \\
\hline $\begin{array}{l}\text { Reading Literacy } \\
\text { grade } 4\end{array}$ & $\begin{array}{l}.39^{* *} \\
.50^{* *}\end{array}$ & $\begin{array}{l}.25^{* *} \\
.00\end{array}$ & $\begin{array}{l}.41^{* *} \\
.36^{* *}\end{array}$ & $\begin{array}{l}.63^{* *} \\
.61^{* *}\end{array}$ & $\begin{array}{l}.51^{* *} \\
.56^{* *}\end{array}$ & $\begin{array}{l}.33^{* *} \\
.29 * *\end{array}$ & $\begin{array}{l}.27^{* *} \\
.30^{* *}\end{array}$ & \\
\hline $\begin{array}{l}\text { Reading Literacy } \\
\text { grade } 6\end{array}$ & $\begin{array}{l}.38^{* *} \\
.40^{* *}\end{array}$ & $\begin{array}{r}.29 * \\
-.08\end{array}$ & $\begin{array}{l}.41^{* *} \\
.49^{* *}\end{array}$ & $\begin{array}{l}.63^{* *} \\
.56^{* *}\end{array}$ & $\begin{array}{l}.55^{* *} \\
.52^{* *}\end{array}$ & $\begin{array}{l}.32 * * \\
.29 * *\end{array}$ & $\begin{array}{l}.32^{* *} \\
.35^{* *}\end{array}$ & $\begin{array}{l}.72 * * \\
.74 * *\end{array}$ \\
\hline
\end{tabular}

$* p<.05, * * p<.01$

regression weights are presented in the model. The fit of the model was good (Chi-square $=31.80, \quad d f=8, \quad p=.00, \quad$ GFI $=.99, \quad$ AGFI $=.95, \quad$ NFI $=.99$, RMSEA $=.063$ ). The model explained $60 \%$ of the variance in Reading Literacy in grade 6 for the L1 students.

As expected the best predictor for Reading Literacy in grade 6 was Reading Literacy in grade 4. Language, Mathematics, and Decoding were strong to moderate 


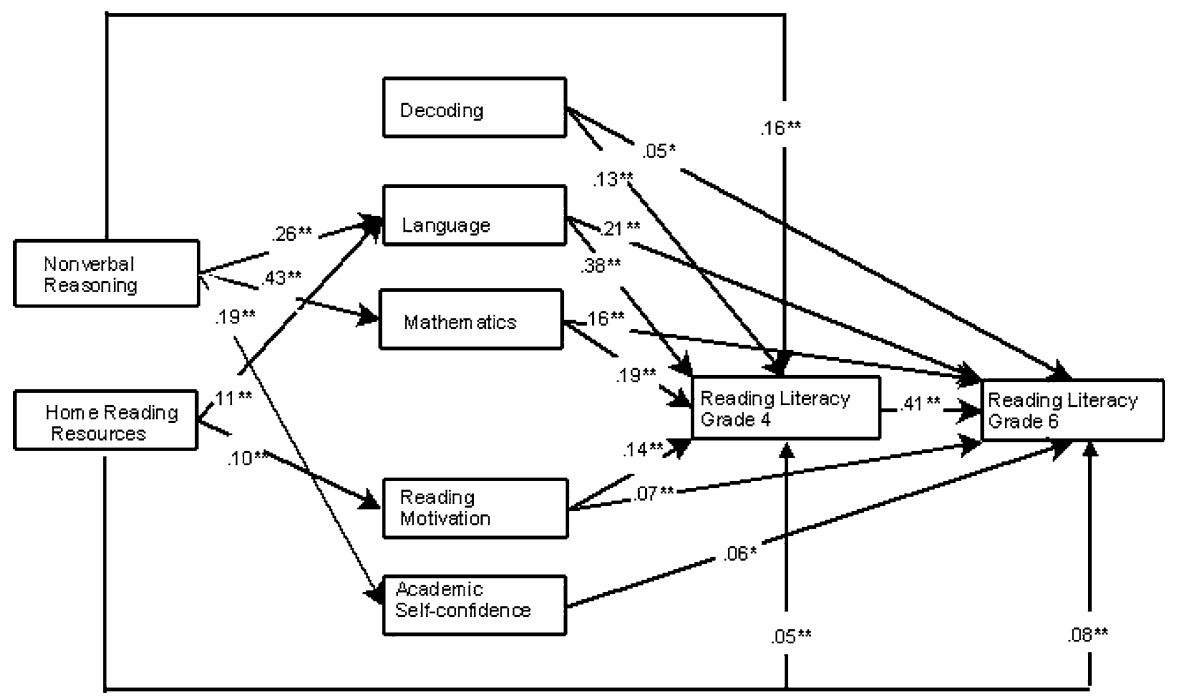

Fig. 1 Structural Model predicting Reading Literacy for L1 learners

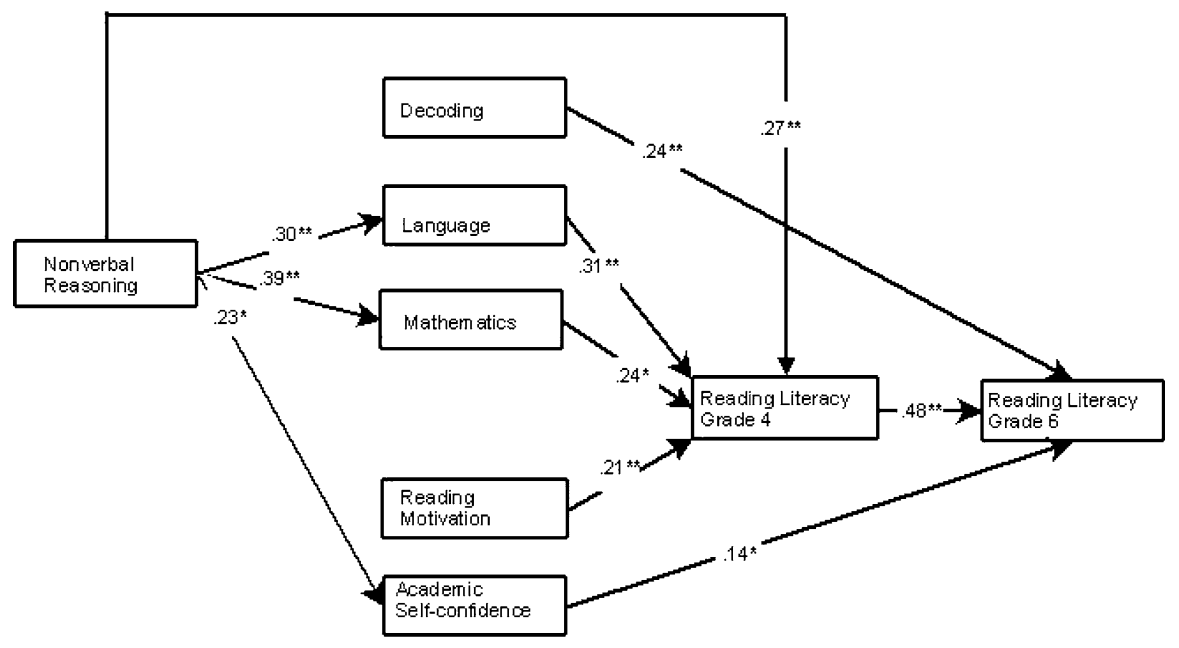

Fig. 2 Structural Model predicting Reading Literacy for L2 learners

predictors for explaining the development in Reading Literacy, whereas the predictive power of Reading Motivation and Academic Self-confidence was small but significant. Furthermore, Nonverbal Reasoning was found to predict Reading Literacy, as well as the intermediate variables of Language, Mathematics, and Academic Self-confidence. Home Reading Resources contributed significantly to the prediction of Reading Literacy and the intermediate variables of Language and reading Motivation. 
Another structural model was constructed for L2 students, entering the same background, intermediate and criterion variables in the model. The result is presented in Fig. 2. The fit of the model was good (Chi-square $=7.30, d f=8$, $p=.5$, GFI $=.98$, AGFI $=.91, \mathrm{NFI}=.98$, RMSEA $=.0$ ). The model explained $63 \%$ of the variance in Reading Literacy in grade 6 for the second language students.

Home Reading Resources did not predict any of the intermediate variables or criterion variables significantly, and is not shown in the model. It can be seen that Reading Literacy in grade 4, Decoding, and Academic Self-confidence were important predictors of Reading Literacy in grade 6 whereas Language, Mathematics, and Reading Motivation significantly predicted Reading Literacy in grade 4. Furthermore, Nonverbal Reasoning predicted Reading Literacy and the intermediate variables Language, Mathematics, and Academic Self-confidence.

\section{Conclusions and discussion}

From the present study several conclusions can be drawn. First of all, the data show that first and second language learners differ in language and reading comprehension scores in the upper grades of Dutch primary schools. This result is conforming with previous studies in the Netherlands (Verhoeven, 2000; Aarnoutse et al., 2001; van Elsäcker, 2002; Droop \& Verhoeven, 2003) and elsewhere (Durgunoglu \& Verhoeven, 1998; Genesee, Lindholm-Leary, Saunders, \& Christian, 2006; Koda, 2007). Significant differences were also found in mathematics and nonverbal reasoning skills. It can be assumed that problems in understanding school-based instruction in Dutch schools may have caused this arrear in nonverbal abilities (cf. Cummins, 2000). Another striking result is that the home reading resources of L2 learners were significantly less as compared to L1 learners. This result has been noted in other studies focusing on the home literacy environment of linguistically diverse groups of learners (de Jong \& Leseman, 2001; van Elsäcker, 2002; van Diepen, 2007; Mullis et al., 2006).

Furthermore, our structural models show that the interrelationships between reading literacy, intermediate school-related abilities and motivations, and nonverbal reasoning skills are highly comparable. In both cases, more than $60 \%$ of the variance in reading literacy by the end of primary school could be explained. For both groups, a strong autoregressive relationship of reading comprehension in grades 4 and 6 was evidenced. This result conforms with the outcome of earlier studies (e.g., Droop \& Verhoeven, 2003; van Elsäcker, 2002), along with a moderate prediction of decoding, language and mathematics, on the one hand, and reading motivation and academic self-confidence, on the other hand. The prediction of reading literacy from word decoding and language conforms with the simple view of reading (Gough \& Tunmer, 1986; Hoover \& Gough, 1990) which was also evidenced in other studies among L2 learners (Proctor, August, Carlo, \& Snow, 2006; Gottardo \& Mueller, 2009). The results show that students who have a positive reading motivation and high self-confidence in grade 4 show better reading literacy abilities in grade 6 . These findings are consistent with the findings of 
previous research on the relationship between reading literacy and reading motivation (Aunola et al., 2002; Wigfield \& Guthrie, 1997; Guthrie \& Wigfield, 2000). Moreover, nonverbal reasoning showed to have a direct impact on reading literacy and its intermediate variables language, mathematics and self-confidence. This result is consistent with previous research which has demonstrated that intelligence is an important predictor for reading literacy (Brooks, Fulker, \& DeFries, 1990; Tiu, Thompson, \& Lewis, 2003), especially in the latter grades (Stanovich, Cunningham, \& Feeman, 1984).

A striking difference in the two models concerned the role of home reading resources. Not only did we find a difference in the amount of resources available, but also in its predictive power. For L1 learners, home reading resources appeared to have an impact on reading literacy and on children's language abilities and reading motivation. For the L2 learners, however, a relationship between home reading resources and criterion as well as predictor measures was generally lacking. It can tentatively be concluded that other factors, such as the socio-cultural orientation and language use within immigrant families, may have suppressed the relationship between home reading resources and children's reading literacy skills. A similar conclusion was also arrived at in other studies focusing on the influence of home literacy environment on a child's reading abilities (Serpell, 2001; Dickinson \& Tabors, 2002; Marks, 2005).

Of course, several limitations apply to the present study. First of all, the size of the group of second language students in our study was rather small. In order to be able to arrive at more definite answers to the question of differences in the literacy development of first and second language learners larger samples are needed. Moreover, our sample of L2 learners can be considered quite heterogeneous which makes it hard to generalize the results. This is especially the case for relationships between reading literacy and variables in the socio-cultural domain (cf. Driessen, 2001). Furthermore, the operationalization of background variables can be improved in future studies by using observations instead of questionnaires. By introducing naturalistic variables in the domain of home reading resources the validity of outcomes can be enhanced (cf. Wasik, 2004).

The results of the present study show a considerable difference in reading literacy ability between first and second language learners at the end of primary school. Since school success relies partly on reading abilities, this difference has important consequences for society. When students enter primary school, or preferably even before that, the students at risk at falling behind should receive additional language instruction. Trying to prevent the gap from forming or at least to break the cycle as soon as possible. Lesaux and Siegel (2003) found in a longitudinal study that a model of early identification and intervention for second language students at risk of falling behind in grade 1 resulted in latter grades in an achievement level in reading and spelling comparable with their L1 peers. In the case of the Dutch second language students, a content-based approach could be followed with an intervention focused on vocabulary acquisition and oral language proficiency (Droop \& Verhoeven, 2003). Although some research has claimed that the influence of decoding skills would be relatively more important in earlier grades and not at the end of primary education (Joshi et al., 1998), the present study suggests that 
decoding skills remain important throughout primary education. This is in line with previous research showing that speed of single word reading accounts for a large amount of the variance in reading comprehension ability (Perfetti, 1985). Finally, continuity between home and school experiences can be seen as critical in the context of cultural and linguistic diversity (Dickinson \& Tabors, 2002). School teams should give room to parental involvement in perspective of continuity of literacy experiences. It is by bridging the gap between literary socialization in the home and literacy education at school that the motivation, engagement, and participation of students in classroom instruction can be enhanced.

Open Access This article is distributed under the terms of the Creative Commons Attribution Noncommercial License which permits any noncommercial use, distribution, and reproduction in any medium, provided the original author(s) and source are credited.

\section{References}

Aarnoutse, C., van Leeuwe, J., Voeten, M., \& Oud, H. (2001). Development of decoding, reading comprehension, vocabulary and spelling during the elementary school years. Reading and Writing: An Interdisciplinary Journal, 14, 61-89.

Adlof, S. M., Catts, H. W., \& Little, T. D. (2006). Should the simple view of reading include a fluency component? Reading and Writing: An Interdisciplinary Journal, 19, 933-958.

Aunola, K., Nurmi, J. E., Niemi, P., Lerkkanen, M. K., \& Rasku-Puttonen, H. (2002). Developmental dynamics of achievement strategies, reading performance, and parental beliefs. Reading Research Quarterly, 37, 310-327.

Brooks, A., Fulker, D. W., \& DeFries, J. C. (1990). Reading performance and general cognitive ability: A multivariate genetic analysis of twin data. Personality and Individual Differences, 11(2), 141-146.

Cox, K. E., \& Guthrie, J. T. (2001). Motivational and cognitive contributions to students' amount of reading. Contemporary Educational Psychology, 26(1), 116-131.

Cummins, J. (2000). Language, power, and pedagogy. Bilingual children in the crossfire. Clevedon, England: Multilingual Matters.

de Jong, P. F., \& Leseman, P. M. (2001). Lasting effects of home literacy on reading achievement in school. Journal of School Psychology, 39(5), 389-414.

Dickinson, D., \& Tabors, P. (2002). Fostering language and literacy in classrooms and homes. Young Children, 57(2), 10-18.

Driessen, G. (2001). Ethnicity, forms of capital, and educational achievement. International Review of Education, 47(6), 513-538.

Driessen, G., van Langen, A., \& Vierke, H. (2002). Basisonderwijs: veldwerkverslag, leerlinggegevens en oudervragenlijsten, Basisrapportage PRIMA-cohortonderzoek. [Primary school: Fieldwork Report, student information, and parents' questionnaires, Basic report of PRIMA Cohort Study]. Nijmegen, The Netherlands: ITS.

Droop, M., \& Verhoeven, L. (2003). Language proficiency and reading ability in first- and secondlanguage learners. Reading Research Quarterly, 38, 78-103.

Durgunoglu, A. Y., \& Verhoeven, L. (Eds.). (1998). Literacy development in a multilingual context: Cross-cultural perspectives. Mahwah, NJ: Lawrence Erlbaum Associates.

Genesee, F., Lindholm-Leary, K., Saunders, W., \& Christian, D. (2006). Educating English language learners: A synthesis of research evidence. New York, NY: Cambridge University Press.

Geva, E., \& Verhoeven, L. (2000). Basic processes in early second language reading. Scientific Studies of Reading, 4, 261-353. (Special issue).

Gottardo, A., \& Mueller, J. (2009). Are first- and second-language factors related in predicting secondlanguage reading comprehension? Journal of Educational Psychology, 101, 330-344.

Gough, P. B., \& Tumer, W. E. (1986). Decoding, reading, and reading disability. Remedial and Special Education, 7, 6-10. 
Guthrie, J.T., Coddington, C.S., \& Wigfield, A. (in press). Profiles of motivation for reading among African American and Caucasian students. Journal of Literacy Research.

Guthrie, J. T., \& Wigfield, A. (2000). Engagement and motivation in reading. In M. L. Kamil, P. B. Mosenthal, P. D. Pearson, \& R. Barr (Eds.), Handbook of reading research (Vol. 3). Mahwah, NJ: Lawrence Erlbaum Associates.

Hoover, W. A., \& Gough, P. B. (1990). The simple view of reading. Reading and Writing: An Interdisciplinary Journal, 2, 127-160.

Hu, L., \& Bentler, P. M. (1999). Cutoff criteria for fit indexes in covariance structure analysis: Conventional criteria versus new alternatives. Structural Equation Modeling, 6(1), 1-55.

Instituut voor Toegepaste Sociologie (ITS). (1994a). PRIMA taaltoets [PRIMA language test]. Nijmegen, The Netherlands: Author.

ITS. (1994b). Nonverbale intelligentie test: Bijgestelde versie van testreeksen groep 6 ontwikkeld door RION [Nonverbal intelligence test: Adapted from testing series grade 4 developed by RION]. Nijmegen, The Netherlands: Author.

International Association for the Evaluation of Educational Achievement (IEA). (2001). PIRLS 2001 Student Questionnaire. Chestnut Hill, MA: Boston College.

Janssen, J., Kraemer, J. M., \& Noteboom, A. (1995). CITO rekenen-wiskunde [CITO calculating and mathematics]. Arnhem, The Netherlands: CITO.

Jöreskog, K., \& Sörbom, D. (1993). LISREL 8: Structural equation modelling with the SIMPLIS command language. Hillsdale, NJ: Lawrence Erlbaum Associates.

Joshi, R. M., \& Aaron, P. G. (2000). The component model of reading: Simple view of reading made a little more complex. Reading Psychology, 21, 85-97.

Joshi, R. M., Williams, K. A., \& Wood, J. R. (1998). Predicting reading comprehension from listening comprehension: Is this the answer to the IQ debate? In C. Hulme \& R. M. Joshi (Eds.), Reading and spelling: Development and disorder. Mahwah, NJ: Lawrence Erlbaum Associates.

Koda, K. (2007). Reading and language learning: Cross-linguistic constraints of second language reading development. Language Learning, 57, 1-44.

Lerkkanen, M. K., Rasku-Puttonen, H., Aunola, K., \& Nurmi, J. E. (2005). Mathematical performance predicts progress in reading comprehension among 7-year olds. European Journal of Psychology of Education, 20(2), 121-138.

Lesaux, N. K., \& Siegel, L. S. (2003). The development of reading in children who speak English as a second language. Developmental Psychology, 39, 1005-1019.

Lundberg, I., \& Sterner, G. (2005). Reading, arithmetic, and task orientation: How are they related? Annals of Dyslexia, 56(2), 361-376.

Marks, G. N. (2005). Accounting for immigrant non-immigrant differences in reading and mathematics in twenty countries. Ethnic and Racial Studies, 28(5), 925-946.

Meece, J. L., Bower-Glienke, B., \& Burg, S. (2006). Gender and motivation. Journal of School Psychology, 44, 351-373.

Mullis, I. V. S., Kennedy, A. M., Martin, M. O., \& Sainsbury, M. (2006). Assessment framework and specifications (2nd ed.). Chestnut Hill, MA: Boston College.

Mullis, I. V. S., Martin, M. O., Gonzales, E. J., \& Kennedy, A. M. (2003). PIRLS 2001 international report. IEA's study of reading literacy achievement in primary school in 35 countries. Boston, MA: International Study Center, Lynch School of Education, Boston College.

Mullis, I. V. S., Martin, M. O., Kennedy, A. M., \& Foy, P. (2007). PIRLS 2006 international report. Boston, MA: International Study Center, Lynch School of Education, Boston College.

Organisation for Economic Co-operation, Development (OECD). (2007). PISA 2006 science competencies for tomorrow's world. Paris, France: Author.

Perfetti, C. A. (1985). Reading ability. New York, NY: Oxford University Press.

Perfetti, C. A., Landi, N., \& Oakhill, J. (2005). The acquisition of reading comprehension skill. In M. J. Snowling \& C. Hulme (Eds.), The science of reading: A handbook (pp. 227-247). Oxford, England: Basil Blackwell.

Proctor, C. P., August, D., Carlo, M. S., \& Snow, C. E. (2006). The intriguing role of spanish language vocabulary knowledge in predicting English reading comprehension. Journal of Educational Psychology, 98, 159-169.

Serpell, R. (2001). Cultural dimensions of literacy promotion and schooling. In L. Verhoeven \& C. Snow (Eds.), Literacy and motivation: Reading engagement in individuals and groups (pp. 243-273). Mahwah, NJ: Lawrence Erlbaum Associates Publishers. 
Snow, C. E., \& Beals, D. E. (2006). Mealtime talk that supports literacy development. New Directions for Child and Adolescent Development, 111, 51-66.

Stanovich, K., Cunningham, A., \& Feeman, D. J. (1984). Intelligence, cognitive skills and early reading processes. Reading Research Quarterly, 19, 175-190.

Staphorsius, G., \& Krom, R. (1998). CITO toetsen begrijpend lezen [CITO Reading Comprehension Tests]. Arnhem, The Netherlands: CITO.

Tabors, P., \& Snow, C. (2001). Young bilingual children and early literacy development. In S. Neuman \& D. Dickinson (Eds.), Handbook of early literacy research (pp. 159-178). New York, NY: Guilford Press.

Tiu, R. D., Thompson, L. A., \& Lewis, B. A. (2003). The role of IQ in a component model of reading. Journal of Learning Disabilities, 36, 424-436.

van der Veen, I., van der Meijden, A., \& Ledoux, G. (2004). School en klaskenmerken basisonderwijs. Basisrapportage PRIMA-cohortonderzoek. Vijfde meting 2002-2003. [School and class characteristics in primary education: Report PRIMACohort study. Fifth measurement 2002-2003]. Amsterdam, The Netherlands: SCO.

van Diepen, M. (2007). Variation in reading literacy: A cross-national approach. Nijmegen, The Netherlands: Radboud University.

van Elsäcker, W. (2002). Development of reading comprehension: The engagement perspective. Enschede, The Netherlands: Feboprint.

Verhoeven, L. (1995). Drie Minuten Toets [Three Minutes Test]. Arnhem, The Netherlands: CITO.

Verhoeven, L. (2000). Components in early second language reading and spelling. Scientific Studies of Reading, 4(4), 313-330.

Wang, M., Perfetti, C. A., \& Liu, Y. (2005). Chinese-English biliteracy acquisition: Cross-language and writing system transfer. Cognition, 97, 67-88.

Wasik, B. H. (Ed.). (2004). The handbook of family literacy. Mahwah, NJ: Lawrence Erlbaum Associates.

Wigfield, A., \& Guthrie, J. T. (1997). Relations of children's motivation for reading to the amount and breadth of their reading. Journal of Educational Psychology, 89, 420-432. 